\title{
ARTIKEL STRUKTUR DATA INFORMATIKA DALAM PEMBELIAN TIKET PESAWAT
}

\author{
Herli Mardiansyah \\ 175110011
}

Universitas Mitra Indonesia, Teknik Informatika

Herlimardiansyah.students@umitra.ac.id

\begin{abstract}
ABSTRAK
Sering kita mendengar istilah database, apa itu database? Menurut beberapa sumber, database merupakan salah satu komponen yang penting didalam sistem informasi, karena berfungsi sebagai basis penyedia informasi bagi para pemakainya. Di dalam database juga ada penerapan database dalam bentuk sistem informasi disebut dengan database sistem. Sistem basis data ini adalah suatu sistem informasi yang mengitegrasikan kumpulan dari data yang saling berhubungan satu dengan yang lainnya dan membuatnya tersedia untuk beberapa aplikasi yang bermacam-macam di dalam suatu organisasi.
\end{abstract}

Kata Kunci:struktur data informatika, dalam program algoritma 
A. PENDAhULUAN

- Struktur data adalah model logika/matematik yang secara khusus mengorganisasi dataatau cara penyimpanan,pengaturan,pengorganisasian dan penyusunan data-data pada memori komputer maupun file secara efektif sehingga dapat digunakan secara efisien, termasuk operasi-operasi di dalamnya. Struktur data adalah cara menyimpan atau merepresentasikan data di dalam komputer agar bisa dipakai secara efisien Sedangkan data adalah representasi dari fakta dunia nyata.

- Fakta atau keterangan tentang kenyataan yang disimpan, direkam atau direpresentasikan dalam bentuk tulisan, suara, gambar, sinyal atau simbol Operasi terhadap data $\longrightarrow$ Tempat Penyimpanan Data

- Traversal (Traversing) : mengunjungi setiap elemen SD

- Pencarian (Searching) : menemukan elemen/lokasi pada SD

- Penyisipan (Inserting) : menambah elemen baru pada SD

- Penghapusan (Deleting) : menghapus elemen dari SD

\section{B.TINJAUAN PUSTAKA}

Berdasarkan judul artikel, di perlukan pengertian menurut para ahli STRUKTUR DATA INFORMATIKA DALAM PEMBELIAN TIKET PESAWAT

- Menurut The Liang Gie : Hal, peristiwa atau kenyataan lainnya apapun yang mengandung sesuatu pengetahuan untuk dijadikan dasar guna penyusunan keterangan, pembuatan kesimpulan/penerapan keputusan.Data adalah ibarat bahan mentah yang melalui pengolahan tertentu lalu menjadi keterangan (informasi).

\section{STUDI KASUS}

Penerapan struktur data dalam aplikasi pembelian tiket pesawat dengan menggunakan struktur data dequeque yang merupakan pengambilan struktur data yg sudah masuk di urutan pertama.sehingga kita tinggal membaca data yang ada posisi heat, inilah fungsi dari heat. Jangan lupa kita cek lebih dulu apakah queue kosong atau tidak tapi jika ada isinya, setelah data diambil,data dibelakangnya digeser kedepan.

-clear

Operasi clear di gunakan untuk menghapus data yang ada di dalam queue. -view

Operasi ini di gunakan untuk melihat data yang ada didalam queue.caranya adalah dengan membaca data pada index yang terdapat diantara head sampai tail.pertama kali

Queue sendiri merupakan antrian, dimana data yang datang pertama kali akan dipanggil juga.penjambaran diatas merupakan cara pembelian tiket pesawat menggunakan aplikasi computer yang menggunakan struktur data sebagai 
dasar pengembangannyasaat mengantri di loket untuk membeli tiket istilah tiket yang di pakai seseorang untuk masuk dalam sebuah antrian adalah dequeue.

\section{Cari Penerbangan}

1.Mencari tiket penerbangan kini lebih mudah dan aman bersama tiket.com. Temukan maskapai sesuai jadwal dan tujuan penerbangan yang Anda inginkan

\section{Pilih Penerbangan}

Kami menampilkan penawaran terbaik dari setiap maskapai pada rute penerbangan yang Anda tentukan. Pilihlah sesuai dengan jadwal, fasilitas, dan harga yang Anda inginkan.

Ringkasan pencarian

Informasi jam penerbangan

Status penerbangan Langsung dan Transit

Fasilitas yang tersedia

Klik "Pesan Sekarang"

\section{Rincian Data Penumpang}

Tidak hanya membantu kami, kelengkapan data diri penumpang juga membantu Anda dalam kenyamanan perjalanan. Untuk itu, jangan lupa untuk mengisi data diri penumpang yang akan berangkat dengan lengkap dan benar.

Ringkasan pencarian

Pilih "Login" untuk mempercepat proses

Pilih title "Tuan, Nyoya dan Nona"

Masukkan alamat email. Pastikan alamat email benar dan aktif

Masukkan nama pemesan

Masukkan nomor telepon yang dapat dihubungi 
Ceklist jika penumpang adalah orang yang sama dengan informasi kontak yang dapat dihubungi

Masukkan nama penumpang,pastikan data penumpang sesuai dengan kartu indentitas

Pilih title "Tuan, Nyoya dan Nona"

Ceklist "YA" jika anda ingin menambahkan perlindungan dalam perjalanan Anda

Klik "Pesan Sekarang”

\section{Pembayaran}

Berbagai macam metode pembayaran telah kami sediakan untuk keamanan dan kenyamanan transaksi Anda. Pilih metode pembayaran yang sesuai dengan kebutuhan Anda.

\section{Metode Pembayaran Tiket Pesawat di tiket.com}

5.1 Pembayaran Dengan Kartu Kredit

$+$

5.2 Pembayaran Dengan Bank BCA

$+$

5.3 Pembayaran Dengan Bank Mandiri

$+$

5.4 Pembayaran Dengan Bank BNI

$+$

5.5 Pembayaran Dengan ATM Transfer

$+$

5.6 Pembayaran Dengan CIMB Clicks

$+$

5.7 Pembayaran Dengan ePay BRI

$+$

\section{Pengiriman Voucher Pesawat}


Setelah pembayaran sukses diterima, Anda akan menerima SMS dan email berisi ringkasan voucher pesawat secara instan, maksimum dalam 60 menit.

\section{DISKUSI}

\section{APAKAH STRUKTUR DATA DALAM PEMBELIAN TIKET PESAWAT ITU PENTING ?}

A : saya sering mendengar istilah struktur data, terkadang kebanyakan orang masih bingung nih struktur data dalam tiket pesawat itu penting atau tidak?

B : Struktur data adalah model logika/matematik yang secara khusus mengorganisasi dataatau cara penyimpanan,pengaturan,pengorganisasian dan penyusunan data-data pada memori komputer maupun file secara efektif sehingga dapat digunakan secara efisien, termasuk operasi-operasi di dalamnya.

C : dalam kehidupan sehari-hari struktur data sangat membantu pekerjaan dalam pembelian tiket pesawat , contohnya di gunakan melalui online,antrian di loket .

\section{KESIMPULAN}

Jadi dapat disimpulkan bahwa Penerapan struktur data dalam aplikasi pembelian tiket pesawat dengan menggunakan struktur data dequeque yang merupakan pengambilan struktur data yg sudah masuk di urutan pertama.sehingga kita tinggal membaca data yang ada posisi heat, inilah fungsi dari heat.

\section{F. REFERENSI}

[1] PUTRA, Arie Setya; FEBRIANI, Ochi Marshella. Knowledge Management Online Application in PDAM Lampung Province. In: Prosiding International conference on Information Technology and Business (ICITB). 2018. P. 181-187.

[2] FEBRIANI, Ochi Marshella; PUTRA, Arie Setya. Sistem Informasi Monitoring Inventori Barang Pada Balai Riset Standardisasi Industri Bandar Lampung. Jurnal Informatika, 2014, 13.1: 90-98

[3] Putra, A. S. (2018, July 9). 2018 Artikel Struktur Data , Audit dan Jaringan Komputer. Retrieved from osf.io/3uq8w

[4]publik lampung (2018,januari). Struktur data.

[5]vinsen (2015,mey). Queue dan dequeue. 